\title{
Effects of Different Genotypes of Switchgrass as a Bioenergy Crop on Yield Components and Bioconversion Potential
}

\author{
Doohong Min 1*, Yadhu N. Guragain², Vara Prasad1, Praveen V. Vadlani², Jungeun Lee² \\ ${ }^{1}$ Department of Agronomy, Kansas State University, Manhattan, KS, USA \\ ${ }^{2}$ Department of Grain Science \& Industry, Kansas State University, Manhattan, KS, USA \\ Email: ^dmin@ksu.edu
}

How to cite this paper: Min, D., Guragain, Y.N., Prasad, V., Vadlani, P.V. and Lee, J. (2017) Effects of Different Genotypes of Switchgrass as a Bioenergy Crop on Yield Components and Bioconversion Potential. Journal of Sustainable Bioenergy Systems, 7, 27-35.

https://doi.org/10.4236/jsbs.2017.71003

Received: February 14, 2017

Accepted: March 6, 2017

Published: March 9, 2017

Copyright () 2017 by authors and Scientific Research Publishing Inc. This work is licensed under the Creative Commons Attribution International License (CC BY 4.0).

http://creativecommons.org/licenses/by/4.0/

(c) (i) Open Access

\begin{abstract}
Switchgrass (Panicum virgatum $\mathrm{L}$.) is a native warm-season grass and it is one of potential bioenergy crops. The objectives of this study were to: 1) assess the best performing switchgrass genotype suitable for Kansas soil and climatic condition in the USA, 2) determine the correlation between plant height or tiller numbers per plant and dry biomass of various switchgrass genotypes, and 3) assess a bioconversion efficiency of certain varieties of switchgrass. Twenty-two different genotypes of seedlings were allowed to grow in cones for 30 days under controlled environments. The genotype Cave-in-Rock was the shortest among the genotypes. Significant difference in number of tillers per plant was observed among the genotypes. The genotypes Alamo recorded the highest numbers of tiller plant ${ }^{-1}$ and the genotype Cave-in-Rock had the lowest numbers of tiller plant ${ }^{-1}$ compared with other genotypes. The genotypes Alamo, NL 94 C2-2, NL 94 C2-3, NSL 2009-1 and NSL 2009-2 had increased above ground biomass compared with other genotypes. The correlation study indicates that there was a significant positive correlation between number of tillers per plant and per plant dry weight $\left(R^{2}=0.93\right)$, number of tillers per plant and plant height $\left(\mathrm{R}^{2}=0.94\right)$, and plant height and per plant dry weight $\left(\mathrm{R}^{2}=0.82\right)$. Based on the biomass composition, the SWG 2007-2 genotype was the promising switchgrass line for the bioconversion through the sugar platform route due to high carbohydrate and low lignin content. On the other hand, the high biomass yield per unit area of field in NL 94 C2-1 led this genotype with the highest total carbohydrate yield per unit area of field despite the lowest total carbohydrate content in the genotype. These results are pertinent for crop breeders to develop the most promising switchgrass line with high biomass yield and high bioconversion efficiency to produce biofuel through the sugar platform route.
\end{abstract}




\section{Keywords}

Switchgrass, Genotype, Bioenergy Crop, Plant Height, Tiller Numbers, Yield, Bioconversion

\section{Introduction}

Biomass is a term for all organic material that comes from plants such as trees and crops. Biomass has always been a major source of energy for mankind and is presently estimated to contribute to the order $10 \%-14 \%$ of the world's energy supply [1]. Due to increasing fuel costs and the uncertainty of fossil fuel supply on the planet, developing bioenergy crop from biomass such as switchgrass might play an important role in terms of diversifying energy sources and increasing energy sustainability. There are many potential bioenergy crops and switchgrass is one of them. Switchgrass is a warm-season perennial plant native to North America that has wide range of adaptation. Since switchgrass is perennial life cycle, it doesn't require annual establishment and fewer chemical inputs such as pesticides and fertilizer. Its traditional uses were native range plants as pasture, roadside plants for erosion control, and a component of conservation reserve program (CRP). As one of the main goals of the Department of Energy (DOE)'s Bioenergy Feedstock Development Program (BFDP), switchgrass was chosen as the main herbaceous plant because of its high biomass, perennial nature, its adaptability to poor soils and marginal cropland [2]. Switchgrass has also been selected as model herbaceous crop for the Oak Ridge National Laboratory, Biofuels Feedstock Program [3]. In recent years, switchgrass has become the most popular and advanced herbaceous perennial feedstock [4]. The Biofuel Analysis Meta-Model energy model predicted that switchgrass could produce greater than $700 \%$ more output than input energy [5]. Not many research was conducted what traits (phenotype and bioconversion) in switchgrass are important as potential feedstock. The objectives of this study were to: 1) assess the best performing switchgrass genotype suitable for Kansas soil and climatic condition in the USA, 2) determine the correlation between plant height or tiller numbers per plant and dry biomass of various switchgrass genotypes, and 3) assess a bioconversion efficiency of certain varieties of switchgrass as a bioenergy crop.

\section{Materials and Methods}

Seeds of twenty two accessions of switchgrass from Oklahoma State University were sown in trays under greenhouse conditions and transferred into cones after emergence at the Kansas State University North Farm in Manhattan, KS, USA in 2010. Metro-Mix 250 growing medium (Scotts-Sierra Horticultural Products Co., Marysville, $\mathrm{OH}$ ) were used for small pot trial in the greenhouse. In the first two weeks, the seeded pots were watered every day and placed in a tray filled with about $5 \mathrm{~cm}$ water. As soon as seedlings grew up to about $5 \mathrm{~cm}$ tall, they were transplanted into a $2.5 \mathrm{~cm}$ cone trainer and watered until they were trans- 
planted in 2010 .

Soils for transplanting were prepared, tilled and leveled to good soil for easy transplantation and establishment. Transplanting was done manually in May, 2010. After transplantation, field was irrigated using sprinklers for 7 days. All the accessions were established well. Sixty kilograms of nitrogen fertilizer per ha was applied about $15 \mathrm{~d}$ after establishment. Each plot consists of 6 columns (south to north direction), and a spacing between two neighboring columns is $30 \mathrm{~cm}$. Ten plants were included in each column. A spacing between two neighboring plants in a column is $30 \mathrm{~cm}$. Plot size was $5.4 \mathrm{~m}^{2}(6$ column $\times 0.3 \mathrm{~m} \times 10$ plants per column $\times 0.3 \mathrm{~m})$.

Switchgrass samples were measured and collected in late October in 2011 and 2012. Plant height and number of tillers per plant were measured in five randomly selected plants from each replication. Single plant was hand-harvested and dried in air-forced oven at $50^{\circ} \mathrm{C}$ for 7 days and dry weight was recorded and dry weight was expressed as dry matter g plant ${ }^{-1}$. Switchgrass was harvested with $15 \mathrm{~cm}$ stubble height.

The biomass composition was evaluated for five selected switchgrass genotypes, whose biomass yields were ranging from $1062.1 \mathrm{~g} \cdot \mathrm{m}^{-2}$ to $1441.5 \mathrm{~g} \cdot \mathrm{m}^{-2}$; biomass yields of these selected genotypes were more than the average biomass yields of 22 genotypes $\left(978.5 \mathrm{~g} \cdot \mathrm{m}^{-2}\right)$. The selected genotypes were NSF 2009-2, NL 94 C2-1, NL 94 C2-3, SWG 2007-2, and Kanlow. Biomass composition was analyzed for total carbohydrate polymers (glucan + xylan + arabinan), total lignin (acid-soluble lignin + acid-insoluble lignin) and total extractives (water-soluble extractives + ethanol-soluble extractives) contents using standard protocol [6]. The protocol in brief: The biomass samples with less than $10 \%(\mathrm{w} / \mathrm{v})$ moisture content were ground using a Thomas-Wiley Laboratory Mill (Model 4) fitted with a $2-\mathrm{mm}$ sieve, followed by sieving in a shaker (W.S. Tyler, Model-RX 29, Serial-25225) fitted with two sieves of sizes 20 mesh $(841 \mu \mathrm{m})$ and 80 mesh $(177 \mu \mathrm{m})$. The specific particle size cut ranging from $177 \mu \mathrm{m}$ to $841 \mu \mathrm{m}$ were used for composition analysis. The ground biomass was first extracted in water using Soxhlet extraction set for $24 \mathrm{~h}$ followed by $95 \%$ ethanol extraction for $24 \mathrm{~h}$ in the same extraction set. The water-soluble extractives and ethanol-soluble extractives were separately calculated by evaporating the solvents in flask and drying the flask in hot-air oven at $100^{\circ} \mathrm{C}$ for $12 \mathrm{~h}$. A $0.3 \mathrm{~g}$ dry extractive-free biomass sample was taken in pressure tubes, $3 \mathrm{ml} 72 \%(\mathrm{w} / \mathrm{w})$ sulfuric acid was added in the tube and incubated in water bath at $30^{\circ} \mathrm{C}$ for $60 \mathrm{~min}$. The biomass slurry was diluted to get $4 \%(\mathrm{w} / \mathrm{w})$ sulfuric acid by adding $84 \mathrm{ml} \mathrm{DI}$ water, and autoclaved at $121^{\circ} \mathrm{C}$ for $60 \mathrm{~min}$. The hydrolyzed biomass slurry was filtered through medium porosity $(15 \mu \mathrm{m})$ porcelain filtering crucible using vacuum pump. Glucose, xylose and arabinose contents of the filtrate were measured using HPLC to calculate glucan, xylan and Arabinan content in biomass, respectively, using a conversion factor of $0.90,0.88$, and 0.88 , respectively. The optical density of the filtrate was measure at $320 \mathrm{~nm}$ to calculate acid-soluble lignin. The crucible with residual biomass was dried at $105^{\circ} \mathrm{C}$ in hot-air oven for around 12 
$\mathrm{h}$ and measured the dry weight of residual biomass. The dry crucible was heated at $575^{\circ} \mathrm{C}$ in muffle furnace for around $24 \mathrm{~h}$ and measured the weight of ash. The difference between dry weight of residual biomass and ash was the measure of acid-insoluble lignin.

Average temperature and monthly precipitation are listed in Table 1. Year 2012 was overall drier than year 2011, particularly from May to July. Temperature pattern was consistent with precipitation and year 2012 was on average hotter than year 2011.

Fisher's protected LSD was used for multiple comparisons ( $\alpha=0.05)$ [7]. An experimental design was a randomized complete block with four replications. Data on plant height, tiller numbers per plant, and above ground biomass were collected and analyzed using PROC MIXED in SAS [8].

\section{Results and Discussion}

\subsection{Growth and Yield Components of Switchgrass}

Significant difference in plant height was observed among the genotypes (Table 2) in 2011 (a year after transplanting) and plant height of switchgrass accessions ranged from 124.2 to $193.9 \mathrm{~cm}$. Although a genotype SL 93 C2-2 was the tallest, there was no significant difference between SL 93 C2-2 and NL 94 C2-1, NL 94 C2-2, NL 94 C2-3, NL 94 C2-4, NSL 2009-1, NSL 2009-3, NSL 2009-4, SL 93

Table 1. Monthly 30-year temperature and precipitation averages and departures from average for 2011 and 2012 in Manhattan, Kansas.

\begin{tabular}{|c|c|c|c|c|}
\hline \multirow{2}{*}{ Item } & \multicolumn{2}{|c|}{ 30-Year } & \multicolumn{2}{|c|}{ Departure from average } \\
\hline & Month & Average & 2011 & 2012 \\
\hline \multirow[t]{8}{*}{ Temperature, ${ }^{\circ} \mathrm{C}$} & March & 6.4 & +0.3 & +8.3 \\
\hline & April & 12.5 & +0.8 & +3.0 \\
\hline & May & 18.4 & -0.4 & +2.1 \\
\hline & June & 23.6 & +1.5 & +3.3 \\
\hline & July & 26.6 & +3.2 & -1.0 \\
\hline & August & 25.5 & +1.7 & -0.8 \\
\hline & September & 20.4 & -1.3 & -0.8 \\
\hline & October & 13.6 & +1.4 & +2.7 \\
\hline \multirow[t]{8}{*}{ Precipitation, $\mathrm{mm}$} & March & 63.3 & -29.5 & +6.6 \\
\hline & April & 80.5 & -17.3 & -30.7 \\
\hline & May & 129.3 & +1.8 & -102.1 \\
\hline & June & 144.8 & -23.6 & -60.9 \\
\hline & July & 112.3 & -59.4 & -97.5 \\
\hline & August & 104.7 & -45.5 & +2.3 \\
\hline & September & 87.1 & -50.0 & -45.5 \\
\hline & October & 68.3 & -12.5 & -54.1 \\
\hline
\end{tabular}


Table 2. Growth and yield components of various switchgrass genotypes grown in Manhattan, Kansas in 2011.

\begin{tabular}{|c|c|c|c|}
\hline Entry name & $\begin{array}{l}\text { Plant height } \\
\left(\mathrm{cm} \mathrm{plant}^{-1}\right)\end{array}$ & $\begin{array}{c}\text { Number of tillers } \\
\text { per plant }\end{array}$ & $\begin{array}{l}\text { Above ground biomass } \\
\qquad\left(\mathrm{g} \cdot \mathrm{m}^{-2}\right)\end{array}$ \\
\hline NSL 2009-1 & 195.9 & 18.1 & 1470.1 \\
\hline NSL 2009-2 & 160.4 & 20.7 & 1199.6 \\
\hline NSL 2009-3 & 186.6 & 22.7 & 709.5 \\
\hline NSL 2009-4 & 179.6 & 16.4 & 1193.5 \\
\hline SL 93 C2-1 & 191.4 & 22.0 & 1218.8 \\
\hline SL 93 C2-2 & 193.9 & 21.3 & 1034.1 \\
\hline SL 93 C2-3 & 186.8 & 21.1 & 1025.8 \\
\hline SL 93 C2-4 & 178.4 & 21.5 & 945.5 \\
\hline NL 94 C2-1 & 188.7 & 20.1 & 1441.5 \\
\hline NL 94 C2-2 & 191.4 & 19.2 & 1387.1 \\
\hline NL 94 C2-3 & 186.1 & 18.8 & 1322.5 \\
\hline NL 94 C2-4 & 190.4 & 21.5 & 1077.5 \\
\hline SNU 98 LMBP C1-1 & 119.8 & 11.3 & 455.5 \\
\hline SNU 98 LMBP C1-2 & 140.3 & 17.3 & 504.5 \\
\hline SNU 98 EMBP C1-3 & 110.1 & 13.7 & 510.8 \\
\hline SWG 2007-1 & 177.7 & 20.0 & 1204.5 \\
\hline SWG 2007-2 & 186.6 & 20.6 & 1062.1 \\
\hline SWG 2007-3 & 126.5 & 14.9 & 473.8 \\
\hline SWG 2007-4 & 145.2 & 16.9 & 534.1 \\
\hline Alamo & 176.5 & 24.4 & 1146.5 \\
\hline Kanlow & 170.3 & 15.2 & 1082.5 \\
\hline Cave-in-Rock & 124.2 & 14.3 & 526.5 \\
\hline Mean & 168.5 & 18.7 & 978.5 \\
\hline $\operatorname{LSD}(\alpha=0.05)$ & 26.1 & 5.9 & 301.8 \\
\hline
\end{tabular}

C2-1, SL 93 C2-3 and SWG 2007-2. The Cave-in-Rock is one of the oldest switchgrass variety bred in Illinois in 1958 and it showed the shortest height among the genotypes of switchgrass.

Significant difference $(P<0.05)$ in number of tillers per plant was observed among the genotypes ranging from 14.3 to 24.4 . The genotype Alamo recorded the highest numbers of tiller plant $^{-1}$ (24.4) which was on par with NL 94 C2-1, NL 94 C2-4, NSL 2009-2, NSL 2009-3, SL 93 C2-1, SL 93 C2-2, SL 93 C2-3, SL 93 C2-4, SWG 2007-1 and SWG 2007-2. The genotype Cave-in-Rock had the lowest numbers of tiller plant ${ }^{-1}$ (14.3) compared with other genotypes. Cave-in-Rock variety had a phenotype of both shortest height and lowest numbers of tillers compared to other genotypes.

The genotypes Alamo, NL 94 C2-2, NL 94 C2-3, NSL 2009-1 and NSL 2009-1 
had increased above ground biomass compared with other genotypes. The genotypes SWG 2007-3, SNU 98 LMBP C1-2, SNU 98 EMBP C1-1, Cave-in-Rock and SWG 2007-4 had significantly $(P<0.05)$ lower above ground biomass than other genotypes of switchgrass. On average, a genotype NL 94 C2 that also had both taller plant and more tillers per plant had significantly higher above ground biomass than other genotypes (Table 2).

In 2012 (two years after transplanting), plant height was taller than those in 2011 by on average 17\%. A genotype SNU 98 LMBP C1 (av. $168 \mathrm{~cm})$ showed significantly shorter than NSL $2009(213 \mathrm{~cm})$, SL 93 C2 $(214 \mathrm{~cm})$, NL 94 C2 $(215$ $\mathrm{cm})$, and SWG $2007(195 \mathrm{~cm})$. A variety Cave-in-Rock was significantly shorter than other genotypes such as NSL 2009, SL 93 C2, NL 94 C2, SNU 98 LMBP, and SWG 2007. However, no difference in height was found in Alamo, Kanlow, and Cave-in-Rock. Number of tillers per plant in 2012 ranging from 16.7 to 28.3 was significantly higher than those in 2011 by on average $17 \%$, which is very similar to a height change from 2011 to 2012. A genotype SL93 C2 (28.3) had the highest tiller numbers per plant and SWG 2007-4 (16.7) the lowest. Switchgrass biomass was found to be related to number of phytomers per tiller and rate of phytomer development [9].

Aboveground biomass ranging from 703 to $1615 \mathrm{~g} \cdot \mathrm{m}^{-2}$ in 2012 (Table 3) was significantly higher than those in 2011 by on average $7.3 \%$ (978 $\mathrm{g} \mathrm{per} \mathrm{m}^{-2}$ in 2011

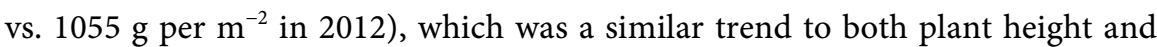
tiller numbers per plant. Number of tillers per plant and above ground biomass in 2012 appeared to be greater than year 2011.

This indicates that as time went by, switchgrass plant size became bigger. Switchgrass has rhizomes, which might have resulted in more tillers and higher above ground biomass. Although Kanlow and Alamo are lowland ecotypes, their average yields over 2011 and 2012 were higher than Cave-in-Rock (highland ecotype). Lowland ecotypes also require a longer growth period [10], a more bunch-type growth and more adapted to wetter sites [11].

The correlation study (data not shown) indicates that there was a significant positive correlation between number of tillers per plant and per plant dry weight $\left(R^{2}=0.93\right)$, number of tillers per plant and plant height $\left(R^{2}=0.94\right)$, and plant height and per plant dry weight $\left(\mathrm{R}^{2}=0.82\right)$. This study might help bioenergy crop breeders develop certain genotypes that can have high biomass with both high number of tillers per plant and taller plant characteristics.

\subsection{Composition of Selected Switchgrass Genotypes}

Figure 1 shows that total carbohydrate, total lignin and total extractives content in five switchgrass genotypes varied from $56.5 \%$ to $59.4 \%, 16.5 \%$ to $18.1 \%$, and $10.6 \%$ to $14.8 \%$, respectively. The SWG 2007-2 genotype had the highest amount of total carbohydrate polymers and the lowest amount of total lignin; therefore, this genotype is the most promising switchgrass line for the bioconversion to produce biofuel through sugar platform route. On the other hand, the Kanlow genotype had the lowest amount of total carbohydrate polymers and highest 


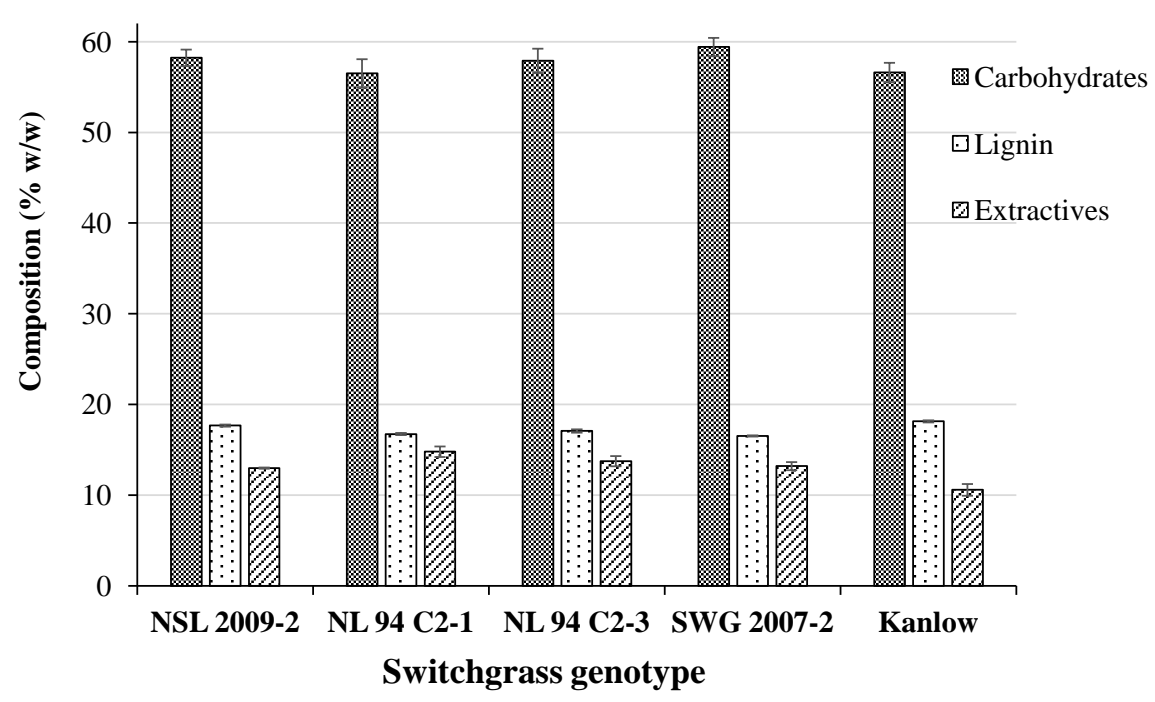

Figure 1. Composition of five selected switchgrass genotypes. Vertical bars indicate standard errors.

Table 3. Growth and yield components of various switchgrass genotypes grown in Manhattan, Kansas in 2012.

\begin{tabular}{|c|c|c|c|}
\hline Entry name & $\begin{array}{l}\text { Plant height } \\
\left(\mathrm{cm} \mathrm{plant}^{-1}\right)\end{array}$ & $\begin{array}{l}\text { Number of } \\
\text { tillers per plant }\end{array}$ & $\begin{array}{l}\text { Above ground biomass } \\
\qquad\left(\mathrm{g} \cdot \mathrm{m}^{-2}\right)\end{array}$ \\
\hline NSL 2009-1 & 219.1 & 24.0 & 981.7 \\
\hline NSL 2009-2 & 210.3 & 23.3 & 1615.5 \\
\hline NSL 2009-3 & 220.6 & 20.4 & 888.1 \\
\hline NSL 2009-4 & 204.2 & 22.1 & 881.5 \\
\hline SL 93 C2-1 & 226.8 & 20.2 & 848.5 \\
\hline SL 93 C2-2 & 217.0 & 25.9 & 850.5 \\
\hline SL 93 C2-3 & 212.4 & 20.8 & 1146.0 \\
\hline SL 93 C2-4 & 203.2 & 28.3 & 1240.9 \\
\hline NL 94 C2-1 & 213.0 & 20.5 & 1278.2 \\
\hline NL 94 C2-2 & 223.9 & 21.4 & 953.1 \\
\hline NL 94 C2-3 & 203.9 & 24.2 & 1428.1 \\
\hline NL 94 C2-4 & 220.9 & 20.0 & 1204.7 \\
\hline SNU 98 LMBP C1-1 & 166.4 & 18.6 & 1006.4 \\
\hline SNU 98 LMBP C1-2 & 183.3 & 19.4 & 1100.0 \\
\hline SNU 98 EMBP C1-3 & 156.8 & 18.3 & 618.3 \\
\hline SWG 2007-1 & 209.9 & 26.6 & 1277.4 \\
\hline SWG 2007-2 & 209.3 & 25.2 & 1593.5 \\
\hline SWG 2007-3 & 182.6 & 25.0 & 830.3 \\
\hline SWG 2007-4 & 178.5 & 16.7 & 972.6 \\
\hline Alamo & 199.7 & 26.8 & 884.3 \\
\hline Kanlow & 200.7 & 23.9 & 703.2 \\
\hline Cave-in-Rock & 176.2 & 23.5 & 908.5 \\
\hline Mean & 201.8 & 22.5 & 1055.1 \\
\hline $\operatorname{LSD}(\alpha=0.05)$ & 23.0 & 6.1 & 420.8 \\
\hline
\end{tabular}


amount of total lignin, thereby making this genotype the least favorable feedstock for biofuel production through sugar platform route.

If the biomass composition data in Figure 1 is combined with the biomass yield per unit area of field (Table 2), total carbohydrate yield per unit area of field can be calculated as shown in Table 4. Table 4 shows that the NL 94 C2-1 genotype had the highest total carbohydrate yield per unit area of field despite the lowest total carbohydrate content in the biomass because of the high biomass yield per unit area of field in this genotype.

In addition, the NL 94 C2-1 genotype had the highest amount of extractives $(14.8 \% \mathrm{w} / \mathrm{w})$; more than $50 \%$ of which were non-structural sugars (glucose, sucrose and fructose). If the non-structural sugar content was included in the total carbohydrate yield per unit area of field calculation, this genotype would have even higher yield. However, further study is needed to confirm the best genotype for bioconversion of switchgrass to produce biofuels.

It is because the bioconversion efficiency depends on a number of factors in addition to gross composition of biomass, including crystallinity of cellulose, lignin structure, and type of linkages among and within the biopolymers (cellulose, hemicellulose and lignin) [12].

\section{Conclusion}

The genotypes, SL 93 C2-2 was the tallest and Cave-in-Rock the shortest among the 22 genotypes. The genotypes Alamo recorded the highest numbers of tiller plant $^{-1}$ and a genotype Cave-in-Rock had the lowest numbers of tiller plant ${ }^{-1}$. The genotypes Alamo, NL 94 C2-2, NL 94 C2-3, NSL 2009-1 and NSL 2009-1 had increased above ground biomass compared with other genotypes. The genotypes SWG 2007-3, SNU 98 LMBP C1-2, SNU 98 EMBP C1-1, Cave-in-Rock and SWG 2007-4 had lower above ground biomass than other genotypes of switchgrass. The correlation study indicates that there was a significant positive correlation between number of tillers per plant and per plant dry weight $\left(\mathrm{R}^{2}=\right.$ 0.93), number of tillers per plant and plant height $\left(R^{2}=0.94\right)$, and plant height and per plant dry weight $\left(\mathrm{R}^{2}=0.82\right)$. The SWG 2007-2 genotype switchgrass had the highest amount of total carbohydrate polymers and the lowest amount of total lignin; therefore, this genotype is the most promising switchgrass line for the bioconversion to produce biofuel through sugar platform route. On the other

Table 4. Total carbohydrate yield per unit area of field.

\begin{tabular}{cccc}
\hline Entry name & $\begin{array}{c}\text { Total carbohydrate } \\
(\mathrm{g} / \mathrm{g} \text { biomass })\end{array}$ & $\begin{array}{c}\text { Biomass yield } \\
\left(\mathrm{g} \cdot \mathrm{m}^{-2}\right)\end{array}$ & $\begin{array}{c}\text { Total carbohydrate } \\
\text { yield }\left(\mathbf{g} \cdot \mathbf{m}^{-2}\right)\end{array}$ \\
\hline NSL 2009-2 & $0.582 \mathrm{ab}$ & 1199.6 & 698.2 \\
NL 94 C2-1 & $0.565 \mathrm{~b}$ & 1441.5 & 814.4 \\
NL 94 C2-3 & $0.579 \mathrm{ab}$ & 1322.5 & 765.7 \\
SWG 2007-2 & $0.594 \mathrm{a}$ & 1062.1 & 630.9 \\
Kanlow & $0.566 \mathrm{~b}$ & 1082.5 & 612.7 \\
\hline
\end{tabular}


hand, the Kanlow genotype had the lowest amount of total carbohydrate polymers and highest amount of total lignin. This study helps bioenergy crop breeders develop certain genotypes that can have high biomass with both high number of tillers per plant and tall plant characteristics and high bioconversion level in switchgrass.

\section{References}

[1] McKendry, P. (2002) Energy Production from Biomass (Part 1): Overview of Biomass. Bioresource Technology, 83, 37-46. https://doi.org/10.1016/S0960-8524(01)00118-3

[2] Bouton, J. (2007) Molecular Breeding of Switchgrass for Use as a Biofuel Crop. Current Opinion in Genetics and Development, 17, 553-558.

https://doi.org/10.1016/j.gde.2007.08.012

[3] McLaughlin, S. (1996) Evaluating Physical, Chemical and Energetic Properties of Perennial Grasses as Biofuels. Proceedings of the BIOENERGY, Nashville, TN, September 1996, USA, 1-8.

[4] Mitchell, R., Vogel, K.P. and Uden, D.R. (2012) The Feasibility of Switchgrass for Biofuel Production. Biofuels, 3, 47-59. https://doi.org/10.4155/bfs.11.153

[5] Farrell, A.E., Plevin, R.J., Turner, B.T., Jones, A.D., O’Hare, M. and Kammen, D.M. (2006) Ethanol Can Contribute to Energy and Environmental Goals. Science, 311, 506-508. https://doi.org/10.1126/science.1121416

[6] Sluiter, A., Hames, B., Ruiz, R., Scarlata, C., Sluiter, J. and Templeton, D. (2007) Determination of Structural Carbohydrates and Lignin in Biomass. National Renewable Energy Laboratory (NREL) Laboratory Analytical Procedures (LAP) for Standard Biomass Analysis.

[7] Steele, R. and Torrie, J. (1980) Principles and Procedures of Statistics: A Biometrical Approach. 2nd Edition, McGraw-Hill, New York.

[8] SAS Institute (2011) SAS/STAT Users Guide 9.3. SAS Inst., Cary, NC.

[9] Boe, A. (2007) Variation between Two Switchgrass Cultivars for Components of Vegetative and Seed Biomass. Crop Science, 46, 636-642.

https://doi.org/10.2135/cropsci2006.04.0260

[10] Moser, L.E. and Vogel, K.P. (1995) Switchgrass, Big Bluestem, and Indiangrass. In: Barnes, R.F., Miller, D.A., Nelson, C.J., Eds., Forages, An Introduction to Grassland Agriculture, 5th Edition, University Press, Ames, IA, 409-420.

[11] Sanderson, M.A., Reed, M.L., McLaughlin, S.B., Conger, S.D., Parrish, D.J., Wolf, D.D., Taliaferro, C., Hopkins, A.A., Ocumpaaugh, W.R., Hussey, M.A., Read, J.C. and Tischler, C.R. (1996) Switchgrass as a Sustainable Bioenergy Crop. Bioresource Technology, 56, 83-93. https://doi.org/10.1016/0960-8524(95)00176-X

[12] Guragain, Y.N., Ganesh, K.M., Bansal, S., Sathish, R.S., Rao, N. and Vadlani. P.V. (2014) Low-Lignin Mutant Biomass Resources: Effect of Compositional Changes on Ethanol Yield. Industrial Crops and Products, 61, 1-8.

https://doi.org/10.1016/j.indcrop.2014.06.014 
Submit or recommend next manuscript to SCIRP and we will provide best service for you:

Accepting pre-submission inquiries through Email, Facebook, LinkedIn, Twitter, etc. A wide selection of journals (inclusive of 9 subjects, more than 200 journals)

Providing 24-hour high-quality service

User-friendly online submission system

Fair and swift peer-review system

Efficient typesetting and proofreading procedure

Display of the result of downloads and visits, as well as the number of cited articles Maximum dissemination of your research work

Submit your manuscript at: http://papersubmission.scirp.org/

Or contact jsbs@scirp.org 